\title{
Gas drainage from different mine areas: optimal placement of drainage systems for deep coal seams with high gas emissions
}

\author{
Ping $\mathrm{Lu}^{1,2} \cdot$ Ping $^{\mathrm{Li}^{3}} \cdot$ Jian $\mathrm{Chen}^{3} \cdot$ Chuijin $\mathrm{Zhang}^{3} \cdot$ Junhua Xue ${ }^{3} \cdot$ Tao $\mathrm{Yu}^{2}$
}

Received: 25 February 2015/Revised: 15 March 2015/Accepted: 16 March 2015/Published online: 21 May 2015

(C) The Author(s) 2015. This article is published with open access at Springerlink.com

\begin{abstract}
The techniques of stress relief mining in low-permeability coal seams and pillarless gob side retained roadway entry using Y-type ventilation and gas drainage systems were developed to control gas outbursts and applied successfully. However, as the mining depth increasing, parts of the gas drainage system are not suitable for mines with high gas emissions. Because larger mining depths cause higher ground stresses, it becomes extremely difficult to maintain long gob side roadways. The greater deformation suffered by the roadway is not favorable for borehole drilling for continuous gas drainage. To solve these problems, Y-type ventilation and gas drainage systems installed from a roof roadway were designed for drainage optimization. This system was designed based on a gas-enrichment zone analysis developed from mining the 11-2 coal seam in the Zhuji Mine at Huainan, Anhui Province, China. The method of Y-type gas extraction from different mine areas was applied to the panel 1112(1) in the Zhuji Mine. The absolute gas emission rate was up to $116.3 \mathrm{~m}^{3} / \mathrm{min}$ with an average flow of $69.1 \mathrm{~m}^{3} / \mathrm{min}$ at an average drainage concentration of nearly $85 \%$. After the Y-type method was adopted, the concentration of gas in the return air was $0.15 \%-0.64 \%$, averaging $0.39 \%$ with a ventilation rate of $2100-2750 \mathrm{~m}^{3} / \mathrm{min}$. The gas management system proved to be efficient, and the effective gas control allowed safe production to continue.
\end{abstract}

Keywords Gas drainage - Different gas sources · Y-type ventilation · Gob side retained roadway · Gas emission · Gas-enrichment zone

\section{Introduction}

China produces more coal than any other country in the world and $95 \%$ of that production is from underground mines (Xie et al. 2012). In the important state-owned mines, $70 \%$ are gassy and coal gas outbursts occur too frequently, mostly from coal seams with low permeability (Yuan 2008a). In recent years, owing to the difficult

Ping Lu

plu2003@163.com

1 Xi' an University of Science and Technology, Xi' an 710054, China

2 Anhui Jianzhu University, Hefei 230022, China

3 Huainan Mining Group Co. Ltd., Huainan 232001, China problem of gas control in low-permeability coal seams, a number of theories, techniques, and instruments have been developed to deal with this problem. The techniques of stress relief mining in low-permeability coal seams, pillarless mining, and Y-type ventilation systems emplaced from gob side retained roadways have been developed and applied successfully to control these gas accidents (Yuan 2008b, 2009). Currently, the Y-type ventilation system gas control technique is being used widely for coal extraction where gas emissions are high (Liu et al. 2009). This gas control technique is beneficial in preventing methane concentrations from rising above the statutory limits, and the selectivity of this gas drainage method is more flexible than U-type ventilation gas control techniques (Xie et al. 2014). The gas drainage methods, which include roadways, surface wells, boreholes drilled from gob side retained 
roadways, and buried pipes in the gob, are applied to control gas emissions during mining coupled with Y-type ventilation (Yuan 2008b). Adopting numerous gas drainage methods together is an important characteristic of this gas control technique. However, as mining depths increase, some elements of this gas control system become unsuitable for seams with high gas emissions. Because the larger mining depths cause higher ground stresses, maintaining long gob side roadways is extremely difficult and the roadways suffer significant deformation. This makes the roadways unsuitable for borehole drilling and continuous gas drainage. Moreover, adopting various gas drainage methods together is lack of the specifically target. Therefore, it is essential to select and optimize a number of different gas drainage methods to manage gas emissions.

\section{Gas-enrichment zones during stress-relief mining}

Gas-enrichment zones in stress relief mining depend upon a number of factors including geological conditions, the number of overlying and underlying seams, the vertical separation of those seams, and the ventilation systems. Figure 1 shows the gas-enrichment zones based on mining the 11-2 coal seam to protect the 13-1 seam at Huainan.

\subsection{Gas-enrichment in an overlying seam}

The 13-1 coal seam at Huainan mining area has a high gas content, low permeability, and low strength. The interval separating 11-2 and the 13-1 seams is between 70 and $90 \mathrm{~m}$. Practical experience in the Panyi Mine showed that, in the stress relief zones in a protected seam, the dilation deformation is up to $2.6 \%$ and the permeability can increase from 0.01 to around $33 \mathrm{~m}^{2}$, an increase of 2880 times (Cheng et al. 2004). Because the interval between the protective and protected seams is large and there is a mudstone layer between the two seams, gas from the protected seam cannot flow into the gob of the protective

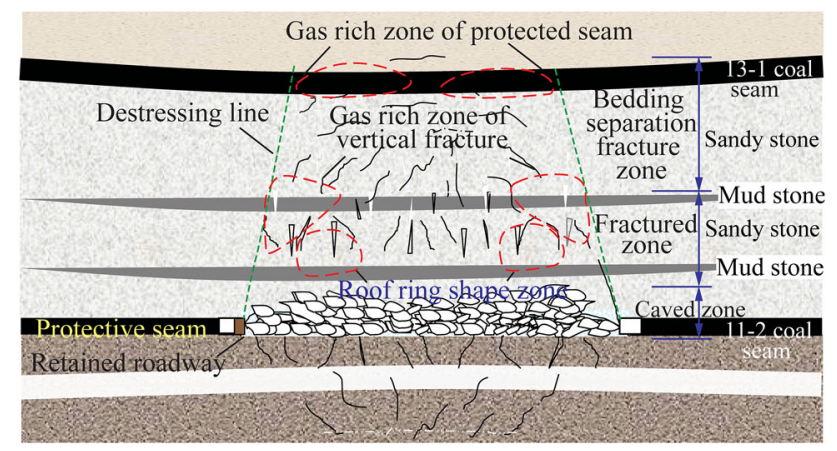

Fig. 1 Distribution of gas-enrichment zones seam despite the permeability of the protected seam being high. The 13-1 coal seam therefore becomes a gas-enrichment zone and gas can be drained through boreholes drilled into the protected seam from a gob side retained roadway and from a 13-1 bottom roadway.

\subsection{Gas-enrichment in the roof}

Extensive studies have been undertaken to characterize the roof gas-enrichment zone in the Huainan mining area. These studies have included physical simulation, numerical modeling, and field measurements, and have shown that a vertical fracture-controlled enrichment zone in the roof strata above the gob is formed after a protective seam is mined (Lu et al. 2010). Owing to irregular piling of rocks in caved zones, this zone is ring shaped. A vertical fracture zone also forms between the caved zone and fractured zone above the gob. These zones allow gas accumulation and movement. The gas in these zones can be desorbed from both overlying and underlying seams as well as desorbed from coal left in the gob. The zone in the roof becomes gas enriched.

\subsection{Gas-enrichment in the gob with a Y-type ventilation system}

The lowest air pressure in the panel occurs at the end of the return roadway, not at the face return corner. A primary path for gas leakage is from the gob into the retained roadway. If the roadway is well sealed against the gob, the gas can accumulate in the gob end and gas concentrations there can be high. The Y-type ventilation system can easily lower gas concentrations in the gob and can contribute to gob gas drainage using buried pipes. A Y-type system can also reduce gas accumulation at the face return corner better than U-type ventilation, which can allow gas concentrations at the upper corner to exceed statutory limits (Yuan et al. 2011).

\section{Practice of gas drainage from different mine areas}

\subsection{Overview of the test panel}

The panel 1112(1) in the Zhuji Mine is the initial mining panel for the 11-2 coal seam in the southeast area. Seam depth is from -910.5 to $-954.3 \mathrm{~m}$, the extractable panel length is $181.8 \mathrm{~m}$ and face length is $220 \mathrm{~m}$. The average thickness of the 11-2 seam is $1.25 \mathrm{~m}$ with a gas content of $5 \mathrm{~m}^{3} / \mathrm{t}$ in the seam and a mining height of $1.8 \mathrm{~m}$ using longwall mining along strike. The 13-1 seam, $64 \mathrm{~m}$ above the 11-2 seam, has a gas content of $9.86 \mathrm{~m}^{3} / \mathrm{t}$ with a 


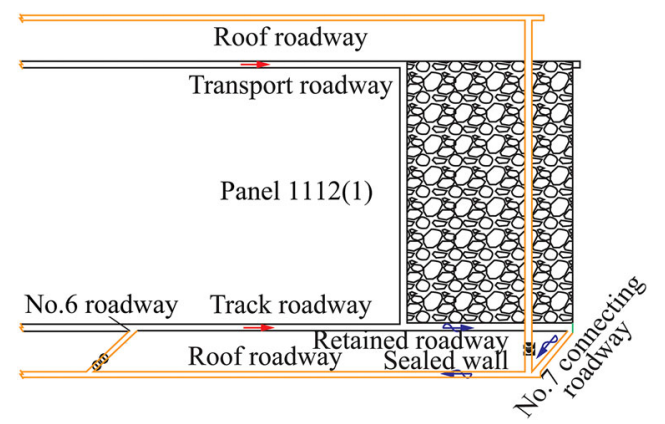

Fig. 2 Roadway arrangement of Y-type ventilation panel

pressure of $6.8 \mathrm{MPa}$. The 13-1 coal seam is an outburst coal seam with low permeability and will be protected by the underlying 11-2 seam. During the mining period, a retained roadway with Y-type ventilation was adopted for gas drainage and seven connecting roadways were used for air return from the retained roadway to a roof roadway, as shown in Fig. 2.

\subsection{Different methods for gas drainage}

\subsubsection{Gas drainage from the stress relief seam, the fracture zone, and the gob by surface wells}

Wells drilled from the surface that penetrated the protected seam, the curved subsidence zone, and the fracture zone and continued to the mining area were superior to construction of roadways for gas drainage because they could be completed without affecting underground mining. During mining, the stress relief gas in the overlying seam, the fracture-enrichment zone, and the gob could be effectively extracted. For the panel 1112(1), nine surface wells were drilled spaced 230-260 m apart and 90-106 m inward from the retained roadway. The surface well coordinates are shown as Table 1.

\subsubsection{Gas drainage from the stress relief seam and fracture-enrichment zone with boreholes from the roof roadway}

When gas is extracted through surface wells, gas migration into the working face cannot be effectively controlled because of the weak drainage effect during a new surface well taking on the main gas drainage role of an old well, because the boreholes of roof strike from transport roadway

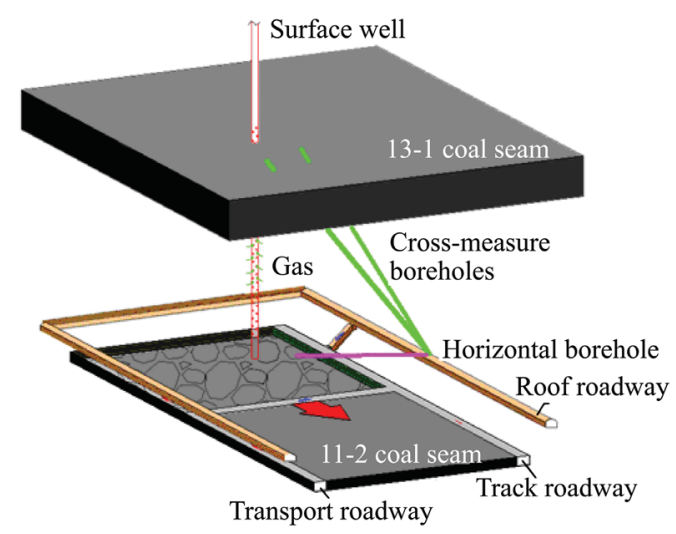

Fig. 3 Three-dimensional drawing showing different methods of gas drainage

have limited influence scope and installing a roof drainage roadway would be time-consuming and difficult. In addition, boreholes drilled from the retained roadway are susceptible to roadway deformation, which commonly results in boreholes being obstructed or sheared off and resultant poor gas removal (Xie and Yang 2010; Zhang et al. 2011). For these reasons, a Y-type ventilation and gas drainage system from the roof roadway is used, as shown in Figs. 3 and 4.

To improve the drainage provided by cross-measure boreholes, a roof roadway was constructed outside of the panel. As shown in Fig. 4, the roadway was driven $20 \mathrm{~m}$ above the 11-2 coal seam and $35 \mathrm{~m}$ horizontally from the retained roadway. This roof roadway has three functions and one additional benefit. The functions are: (1) to serve as an air return path for Y-type ventilation from the working face; (2) to provide stations from which to drill cross-measure boreholes to extract stress relief gas from the 13-1 coal seam; and (3) to allow large-diameter horizontal boreholes to be drilled to the gas-enrichment zone above the gob roof to drain gas from the gob area and to control upper corner gas. The roadway has a fourth benefit in that the roof roadway can be reused as a highlevel drainage roadway for the next phase of 11-2 coal seam panel mining.

Cross-measure boreholes drilled to extract stress relief gas from the 13-1 coal seam are also shown in Fig. 4. To improve stress relief gas extraction, cross-measure boreholes were drilled into the stress relief areas defined in Sect. 2 of this paper. The corresponding elevation angle of cross-measure boreholes in the roof roadway is $26^{\circ}-42^{\circ}$.

Table 1 Locations of surface wells

\begin{tabular}{lllllrrrrr}
\hline Wells & No. 1 & No. 2 & No. 3 & No. 4 & No. 5 & No. 6 & No. 7 & No. 8 & No. 9 \\
\hline Distance along strike (m) & 92 & 321 & 568 & 795 & 1030 & 1288 & 1541 & 1778 & 2018 \\
Distance from retained roadway (m) & 91 & 106 & 89 & 104 & 92 & 91 & 90 & 90 & 90 \\
\hline
\end{tabular}




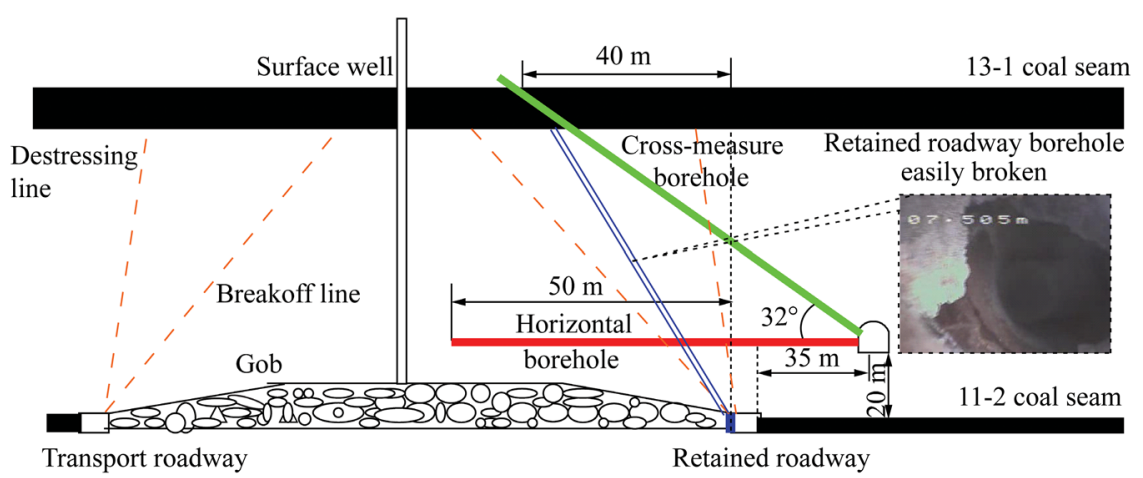

Fig. 4 Design of Y-type roof gas drainage boreholes

The elevation angle of actual operation is $32^{\circ}$ and the azimuth angle is perpendicular to the roof roadway. Each group is spaced 20-25 m apart with two boreholes in each group. Each hole is $113 \mathrm{~mm}$ in diameter.

A third method for gas extraction shown in Fig. 4 is extraction of gas from the fracture zone by large-diameter horizontal boreholes. These holes were bored to maintain low gas concentrations at the upper corner of the working face and were emplaced into the roof fracture zone of the 11-2 coal seam while new surface wells were being drilled. The high-concentration gas in the vertical fracture zone of the roof was extracted by these boreholes. The elevation angle of the boreholes was $0^{\circ}$ and the azimuth was perpendicular to the roof roadway. The $153 \mathrm{~mm}$ boreholes penetrated about $50 \mathrm{~m}$ into the gob and were lined with full-length sieve tubes.

\subsubsection{Gas drainage of gob to the retained roadway with buried pipes}

To account for air leakage in the gob side of the Y-type ventilation, $40 \mathrm{~cm}$ iron pipes were embedded approximately every $20 \mathrm{~m}$ in the filler wall of the retained roadway to extract accumulated gas in the gob area. Based on the observation that negative pressure is greatest at the end of the retained roadway, two $20 \mathrm{~cm}$ iron pipes were embedded in the sealed walls of the connection tunnel between the retained roadway and roof roadway. When a new connection tunnel was opened, the old retained and roof roadways were sealed as shown in Fig. 2.

\subsection{Effect of gas drainage by drainage method}

\subsubsection{Surface well gas drainage}

During mining, alternate drainage of surface wells was accomplished and the maximum gas drainage concentration of a single well could be up to $100 \%$ for each surface well. When the working face was pushed $20 \mathrm{~m}$ past the

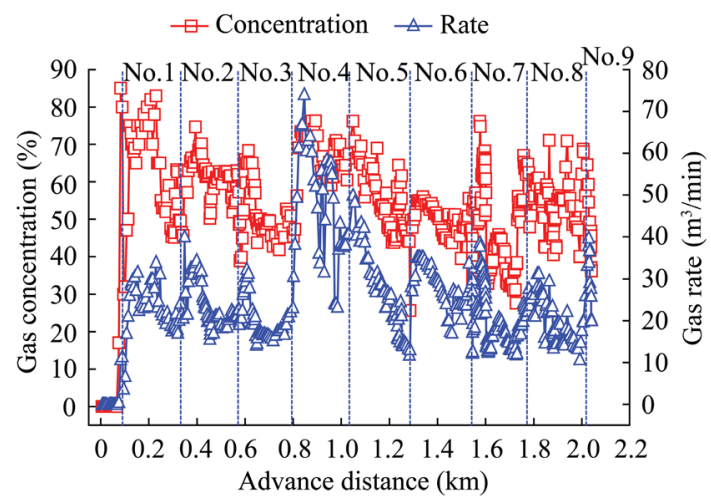

Fig. 5 Gas drainage effect of surface wells

surface well, the quantity of gas continued to be high but then gradually decreased to a lower value. The volume of gas drained was mainly influenced by the condition of the well and geological structure. If the well collapsed or water accumulated in the bore, the quantity of gas drained would drop quickly. If the condition of the surface well remained good, however, the well could function effectively until the mining of that panel ended. Figure 5 is a graph of the gas production from nine surface wells. The dashed lines show the position of each well. The gas drainage rate of surface wells could be up to $85 \mathrm{~m}^{3} / \mathrm{min}$ although the average rate was $23.7 \mathrm{~m}^{3} / \mathrm{min}$. The average gas drainage concentration was $51.8 \%$. Figure 5 shows that there are nine peaks on the gas drainage rate and concentration curves. Each peak was reached after the working face pushed past the well. Note that after the working face pushed past the No. 4 surface well, the gas drainage increased remarkably. This may have been a result of the diameter of the No. 4 well being $244 \mathrm{~mm}$ whereas the other wells were $177 \mathrm{~mm}$ in diameter.

\subsubsection{Roof roadway borehole gas drainage}

The drainage provided by cross-measure and large-diameter horizontal boreholes in the roof roadway is shown 


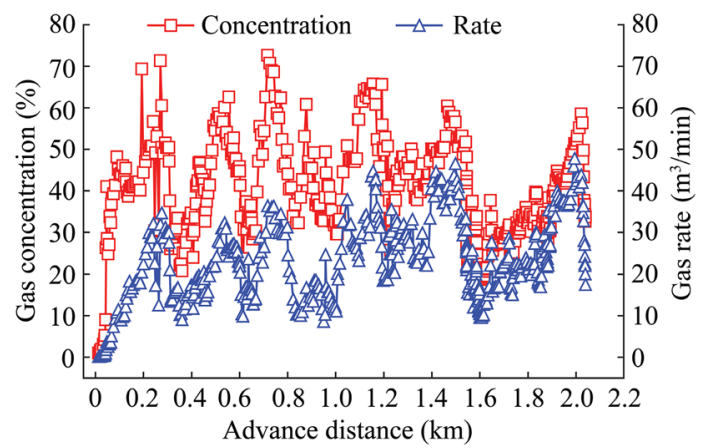

Fig. 6 Gas drainage effect of roof roadway boreholes

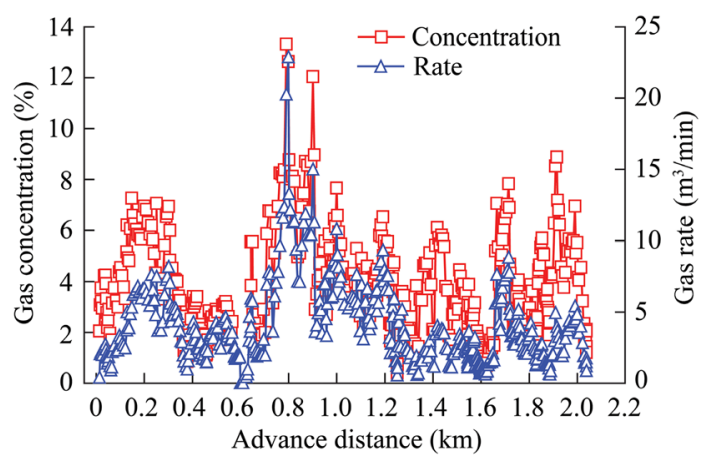

Fig. 7 Gas drainage effect of buried pipes in the filler wall

in Fig. 6. The maximum gas drainage rate reached $47.5 \mathrm{~m}^{3} / \mathrm{min}$; the average was $22.4 \mathrm{~m}^{3} / \mathrm{min}$ during advancement. The concentration of gas drainage was as much as $72.3 \%$ with an average of $38.4 \%$. During surface well replacement, the stress relief gas could be effectively controlled to prevent gas migration to the working face.

\subsubsection{Pipes buried in the gob at the retained roadway gas drainage}

The gas drainage from pipes embedded in filler wall of the roadway is shown in Fig. 7. The gas drainage rate reached $22.8 \mathrm{~m}^{3} / \mathrm{min}$ with an average of $3.6 \mathrm{~m}^{3} / \mathrm{min}$, and the concentration of gas in the drainage was up to $8.9 \%$ (the average was $4.4 \%$ ). The gas drainage provided by pipes buried in the sealed walls of the connection tunnel between the retained roadway and roof roadway is shown in Fig. 8. For this method, the maximum gas drainage rate was $32.8 \mathrm{~m}^{3} / \mathrm{min}$ (average $9.4 \mathrm{~m}^{3} / \mathrm{min}$ ) with a maximum gas concentration of $27.6 \%$ (average $9.9 \%$ ). Buried pipes in the sealed walls promoted gas movement to the deep gob area. When surface wells and roof roadway boreholes were not fully effective, the buried pipes in the sealed walls were the most important part of the gas control system.

In general, Figs. 5, 6, 7, and 8 show that the gas concentrations and quantity peaked about every $100 \mathrm{~m}$ of

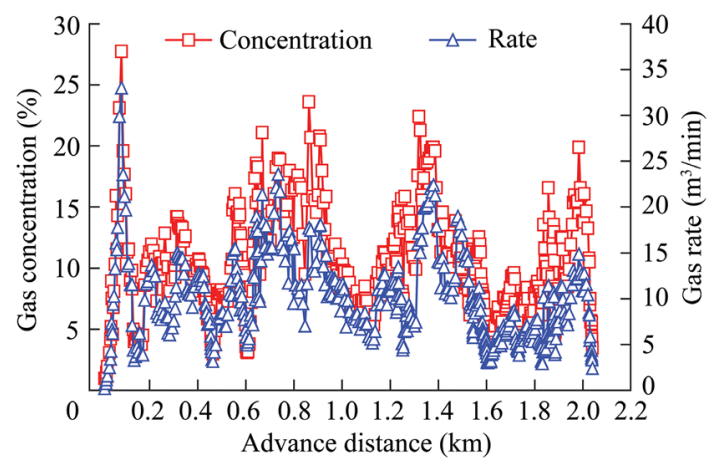

Fig. 8 Gas drainage effect of buried pipes in sealed walls

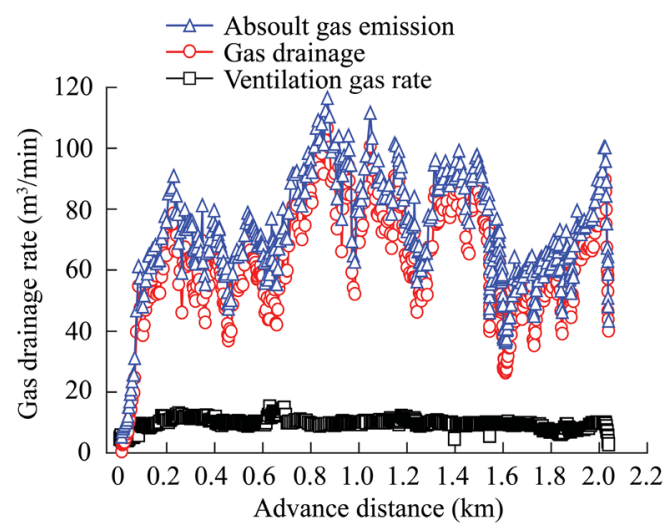

Fig. 9 Gas emission and drainage rate

mining advance. Note the peak positions at $800 \mathrm{~m}$ of advance. The gas curves for buried pipes in the filler walls peak when the panel advanced to $800 \mathrm{~m}$ and at that time, the No. 3 surface well had stopped draining while the No. 4 well had not yet taken effect.

\subsection{Integrated gas drainage results}

Figures 9 and 10 show mine gas emission rates, ventilation and return air rates, and gas concentrations during the mining of the panel 1112(1). The absolute gas emission rate was as much as $116.3 \mathrm{~m}^{3} / \mathrm{min}$; the average was $69.1 \mathrm{~m}^{3} / \mathrm{min}$. The maximum gas drainage rate could reach $106.7 \mathrm{~m}^{3} / \mathrm{min}$ with an average of $59.5 \mathrm{~m}^{3} / \mathrm{min}$ (Fig. 9), and the gas drainage rate averagely accounted for $84.8 \%$ of gas emission rate. The surface wells drained $40.1 \%$ of the total gas, the roof roadway boreholes $37.9 \%$, and buried pipes $22.0 \%$. Figure 10 shows that after the adoption of the Y-type ventilation extraction system, the gas concentration of return air was between $0.15 \%$ and $0.64 \%$ with a ventilation rate of $2100-2750 \mathrm{~m}^{3} / \mathrm{min}$ (only dropping to $1620 \mathrm{~m}^{3} / \mathrm{min}$ just before completion). Thus the gas was effectively controlled during mining and safe production was realized. 


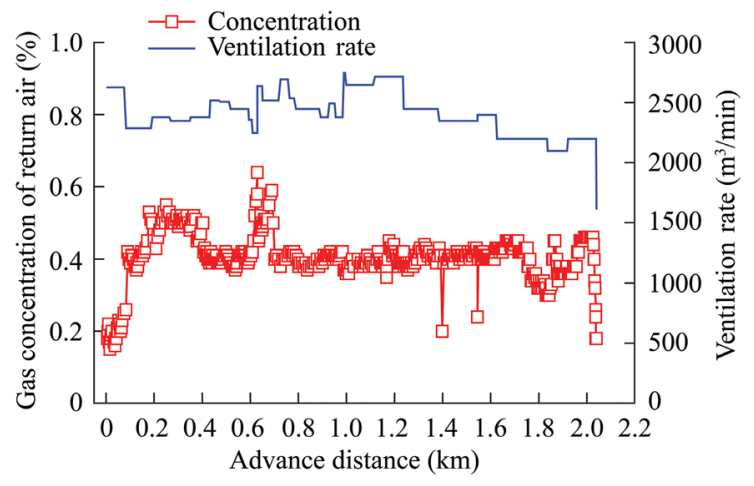

Fig. 10 Gas concentration of return air and ventilation rate

\section{Discussion}

(1) The effectiveness of drainage provided by surface wells is affected by the well type, well condition, and geological structure. Hole collapse or water accumulation can result in poor gas drainage. Good hole conditions can sustain the drainage effect until mining of the panel has been completed. A largerdiameter surface well can improve gas drainage.

(2) Based on drainage analysis of roof roadway boreholes, drainage for these holes can be equivalent to that provided by surface wells. However, considering the cost and construction difficulties, surface wells are expensive and complicated, whereas the roof roadway is simple and flexible with well-known drainage effectiveness. Gas drainage from roof roadway boreholes can be an effective supplement for gas remediation.

(3) Drainage analysis shows that the important features of gob buried pipes are that the drainage mixture amount is great, the gas concentration is low, and their major role is to change the gas flow field in the gob area and keep gas concentrations below the statutory limit at the corner of the retained roadway. Owing to the negative pressure being great at the sealed wall at the end of the retained roadway, the drainage rate and concentration are higher than those at the buried pipes in filler wall.

\section{Conclusions}

(1) During mining of the panel 1112(1) in the Zhuji Mine, the absolute gas emission rate reached $116.3 \mathrm{~m} \mathrm{~m}^{3} / \mathrm{min}$ and averaged $69.1 \mathrm{~m}^{3} / \mathrm{min}$. After the adoption of Y-type ventilation, the concentration of gas in return air was between $0.15 \%$ and $0.64 \%$ with a ventilation rate of $2100-2750 \mathrm{~m}^{3} / \mathrm{min}$. These data show that effective gas control was achieved and coal production could proceed safely.

A roof roadway was driven outside of the mining panel to provide three interrelated gas control features and one ancillary feature. First, to improve the drainage from cross-measure boreholes, the roof roadway acted as an air return pathway for Y-type ventilation air from the working face. Second, the roof roadway allowed the construction of crossmeasure boreholes to extract stress relief gas from the overlying 13-1 coal seam. Third, large-diameter horizontal boreholes could be drilled from the roadway to the gas-enrichment zone above the gob roof to drain gas from the gob area and control gas in the upper corner of the working face. The fourth feature is that, subsequent to panel 1112(1) completion, the roof roadway could be used as a high-level drainage roadway for mining the next panel 11-2.

(3) The gas drainage rate reached $106.7 \mathrm{~m}^{3} / \mathrm{min}$ and averaged $59.5 \mathrm{~m}^{3} / \mathrm{min}$ with an average gas drainage ratio of $84.8 \%$. Surface wells drained $40.1 \%$ of the total amount of gas, roof roadway boreholes drained $37.9 \%$, and the buried pipes accounted for the remaining $22.0 \%$. The effect of the cross-measure and horizontal boreholes was equivalent to that of surface wells, and holes drilled from the roof roadway could be an effective supplement for gas remediation.

Acknowledgments This work was supported by the National Natural Science Foundation of China (41172147), the Anhui Province Science and Technology Research Plan (12010402110), and the Shanxi Province One Hundred Distinguished Professor Plan project.

Open Access This article is distributed under the terms of the Creative Commons Attribution 4.0 International License (http://creativecommons.org/licenses/by/4.0/), which permits unrestricted use, distribution, and reproduction in any medium, provided you give appropriate credit to the original author(s) and the source, provide a link to the Creative Commons license, and indicate if changes were made.

\section{References}

Cheng YP, Yu QX, Yuan L (2004) Experimental research of safe and high-efficient exploitation of coal and pressure relief gas in long distance. J China Univ Min Technol 33(2):132-136

Liu L, Cheng YP, Wang HF, Wang L, Ma XQ (2009) Principle and engineering application of pressure relief gas drainage in low permeability outburst coal seam. Min Sci Technol 19:342-345

Lu P, Yuan L, Cheng H, Xue JH (2010) Theory and experimental studies of enhanced gas drainage in the high gas face of low permeability coal multi-seams. J China Coal Soc 35(4):580-585

Xie GX, Yang K (2010) Study of macro stress shell evolving characteristics of rock surrounding face. Chin J Rock Mech Eng 29:2676-2680

Xie HP, Zhou HW, Xue DJ, Wang HW, Zhang R, Gao F (2012) Research and consideration on deep coal mining and critical mining depth. J China Coal Soc 37(4):535-542 
Xie HP, Zhou HW, Xue DJ, Gao F (2014) Theory technology and engineering of simultaneous exploitation of coal and gas in China. J China Coal Soc 39(8):1391-1397

Yuan L (2008a) Theory and practice of integrated pillar less coal production and methane extraction in multi-seams of low permeability. China Coal Industry Publishing House, Beijing

Yuan L (2008b) Key technique of safe mining in low permeability and methane-rich seam group. Chin J Rock Mech Eng 27(7):1370-1379
Yuan L (2009) Theory of pressure-relieved gas extraction and technique system of integrated coal production and gas extraction. J China Coal Soc 34(1):1-8

Yuan L, Guo H, Shen BT, Qu QD, Xue JH (2011) Circular overlying zone at long wall panel for efficient methane capture of multiple coal seams with low permeability. J China Coal Soc 36(3):357-365

Zhang N, Yuan L, Wang C, Han JG, Hu XL (2011) Deformation characteristics and stability analysis of roof roadway in distressed mining. J China Coal Soc 36(11):1784-1789 